\title{
Role of Engineered Carbon Nanoparticles (CNPs) in Promoting Growth and Metabolism of Vigna radiata (L.) Wilczek: Insights into the Biochemical and Physiological Responses
}

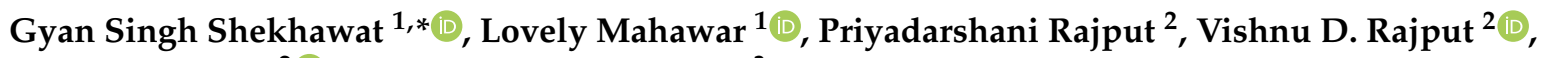 \\ Tatiana Minkina $^{2}$ (D) and Rupesh Kumar Singh ${ }^{3}$ \\ 1 Plant Biotechnology and Molecular Biology Laboratory, Department of Botany, Jai Narain Vyas University, \\ Jodhpur 342001, India; shrilovelymahawar@gmail.com \\ 2 Academy of Biology and Biotechnology, Southern Federal University, 344090 Rostov-on-Don, Russia; \\ priyadarshanirajput22@gmail.com (P.R.); rajput.vishnu@gmail.com (V.D.R.); tminkina@mail.ru (T.M.) \\ 3 Centro de Química de Vila Real, Universidade de Trás-os-Montes e Alto Douro, Quinta de Prados, \\ 5000-801 Vila Real, Portugal; rupeshbio702@gmail.com \\ * Correspondence: gyans.shekhawat@gmail.com; Tel.: +91-9414279665
}

\section{check for} updates

Citation: Shekhawat, G.S.; Mahawar L.; Rajput, P.; Rajput, V.D.; Minkina,

T.; Singh, R.K. Role of Engineered Carbon Nanoparticles (CNPs) in Promoting Growth and Metabolism of Vigna radiata (L.) Wilczek: Insights into the Biochemical and Physiological Responses. Plants 2021, 10, 1317. https://doi.org/10.3390/ plants10071317

Academic Editor: Serenella Nardi

Received: 28 May 2021

Accepted: 25 June 2021

Published: 28 June 2021

Publisher's Note: MDPI stays neutral with regard to jurisdictional claims in published maps and institutional affiliations.

Copyright: (c) 2021 by the authors. Licensee MDPI, Basel, Switzerland. This article is an open access article distributed under the terms and conditions of the Creative Commons Attribution (CC BY) license (https:// creativecommons.org/licenses/by/ $4.0 /)$.

\begin{abstract}
Despite the documented significance of carbon-based nanomaterials (CNMs) in plant development, the knowledge of the impact of carbon nanoparticles (CNPs) dosage on physiological responses of crop plants is still scarce. Hence, the present study investigates the concentrationdependent impact of CNPs on the morphology and physiology of Vigna radiata. Crop seedlings were subjected to CNPs at varying concentrations ( 25 to $200 \mu \mathrm{M}$ ) in hydroponic medium for $96 \mathrm{~h}$ to evaluate various physiological parameters. CNPs at an intermediate concentration (100 to $150 \mu \mathrm{M})$ favor the growth of crops by increasing the total chlorophyll content (1.9-fold), protein content (1.14-fold) and plant biomass (fresh weight: 1.2-fold, dry weight: 1.14-fold). The highest activity of antioxidants (SOD, GOPX, APX and proline) was also recorded at these concentrations, which indicates a decline in ROS level at $100 \mu \mathrm{M}$. At the highest CNPs treatment $(200 \mu \mathrm{M})$, aggregation of CNPs was observed more on the root surface and accumulated in higher concentrations in the plant tissues, which limits the absorption and translocation of nutrients to plants, and hence, at these concentrations, the oxidative damage imposed by CNPs is evaded with the rise in activity of antioxidants. These findings show the importance of CNPs as nano-fertilizers that not only improve plant growth by their slow and controlled release of nutrients, but also enhance the stress-tolerant and phytoremediation efficiency of plants in the polluted environment due to their enormous absorption potential.
\end{abstract}

Keywords: carbon nanoparticles; nano-fertilizers; Vigna radiata; oxidative stress; antioxidants

\section{Introduction}

Nanotechnology is a leading field of science which involves the manipulation of material at the nanoscale (1 to $100 \mathrm{~nm}$ in size) to create functional materials that acquire peculiar properties over their bulk materials. At the nanoscale, carbon-based nanomaterials (CNMs), including fullerenes, nanodots, nanoparticles, nanotubes, nano-horns, nanobeads, nano-diamonds and nanofibers [1], possess novel physiochemical properties such as small surface area, increased chemical reactivity, increased ability to penetrate biological cells and typical surface morphology. These special properties vary from their bulk materials due to the differences in agglomeration shape, small size and surface structure [2], as well as due to the molecular stability of constructive CNMs and their homogeneous dispersive character in the application medium [3]. Carbon-based nanomaterials (CNMs) are explored as drug carrier vehicles and smart delivery systems in several areas of human endeavor, such as nano-pharmacology, nanomedicine, public health, etc. [4,5], for delivery of an appropriate dosage of drugs or other active substances to the specific target site within 
the cell [3]. Similar functions are applicable to plant systems in which CNMs are used as pesticides, growth enhancers, seed sprouts and carriers (DNA, phytohormones, fertilizers, herbicides) to the plant cells [3]. However, CNM applications in plant science, especially in sustainable crop production, have not been thoroughly explored, and hence the impacts of CNMs on plant development are less studied in comparison to the corresponding research on animals [6]. Moreover, certain studies have raised questions about the potential use of nanoparticles in plants to enhance the agricultural productivity regarding their negative impacts on living organisms and surroundings.

The release of carbon nanoparticles into the terrestrial environment through atmospheric deposition, agricultural application, surface runoff or other pathways will accumulate CNPs in higher concentrations in soil because of their poor migration in soil $[7,8]$. Plants are cornerstones of all ecosystems and play an essential role in the fate and transport of CNPs in the environment via uptake (through foliar or root pathways) and bioaccumulation through the food chain [9]. The increased accretion of nanoparticles in the plant tissue affects the plant growth and physiology by inhibiting seed germination, suppressing plant elongation, decreasing plant biomass, altering gene expression and increasing the production of reactive oxygen species (ROS), such as hydrogen peroxide $\left(\mathrm{H}_{2} \mathrm{O}_{2}\right)$, singlet oxygen $\left({ }^{1} \mathrm{O}_{2}\right)$ and hydroxyl radical $\left(\mathrm{OH}^{-}\right)$, that induces oxidation of nucleic acids, proteins, lipids and poses a threat to the bio-membrane, which finally leads to cell death $[7,8]$. To overcome the negative impact of CNPs, plants have a well-developed antioxidant system which comprises of several non-enzymatic (proline, carotenoids, thiols) and enzymatic antioxidants (ascorbate peroxidase, catalase, superoxide dismutase, guaiacol peroxidase, glutathione reductase, heme-oxygenase), that can scavenge the surplus ROS. Heme-oxygenase is a novel discovered enzyme in higher plants that works as an antioxidant against different environmental stress, namely salinity, UV-B and heavy metal stress [10-13]. The enzyme catalyzes the oxidative degradation of Fe (III) protoporphyrin IX to biliverdin IX (BV), carbon monoxide (CO) and iron in the presence of a reducing equivalent (NADPH) [14-16]. These antioxidants show regular activity during normal conditions, but their catalytic reaction is magnified under changing environments [10].

Recently, Li et al. [17] reported that most nanoparticles show adverse effects on crop development at low dosage and positive impacts at high concentrations, which may differ upon changing the morphology, dosage, covering and composition of nanoparticles [17]. Toxic effects of nanoparticles, including root growth inhibition [18-20], formation of reactive oxygen species and rise in peroxidation of membrane lipids [21], have been well-studied in previous research. Conversely, Hong et al. [22] and Yang et al. [23] evaluated the function of $\mathrm{TiO}_{2}$ nanoparticles in promoting plant growth by improving their nitrogen fixation ability. Lu et al. [24] recorded the improved synthesis of nitrate reductase in Glycine max when subjected to $\mathrm{TiO}_{2}$ and $\mathrm{SiO}_{2}$ nanoparticles, which in turn promotes plant growth and seed germination by increasing the water uptake efficiency. Though research in this multidisciplinary field is productive, the scientific research focusing on the impact of carbon-based nanoparticles (CNPs) on plant responses is still scarce. In view of this, the present study highlights the concentration-dependent effect of engineered carbon nanoparticles (CNPs) on crop plants.

To assess this, we studied the interaction between carbon nanoparticles and crop in liquid medium by focusing on the physiological (protein, chlorophyll, oxidative damage and antioxidants) and morphological (plant height and biomass) parameters. These parameters were selected based on the effect of uptake and accumulation of nanoparticles on these physio-morphological parameters, mainly photosynthesis, plant growth and biomass [25]. Vigna radiata was selected as the experimental crop to examine the effect of CNPs dosage, due to its ability to adapt in different environmental conditions. Vigna radiata is an economically important legume crop around the globe and among the important summer legumes, grown predominantly under semi-arid conditions of tropical and subtropical regions. The short lifecycle of the plant facilitates the study of the impact of CNPs in a relatively shorter time period [26,27]. The study is significant as it is helpful to recognize 
the allowable concentration of CNPs on crops so new biotechnological approaches can be developed for plant improvement.

\section{Results}

\subsection{Characterization of $\mathrm{CNPS}$}

The characterization of CNPs using UV-Vis spectroscopy is summarized in Figure 1A. The UV-Vis absorption spectrum (the red line) of CNPs solution shows an absorption peak around the $215 \mathrm{~nm}$ wavelength, while the image obtained from SEM predicts spherical carbon nanoparticles of varying sizes, ranging between 3 and $10 \mathrm{~nm}$ (Figure 1B).
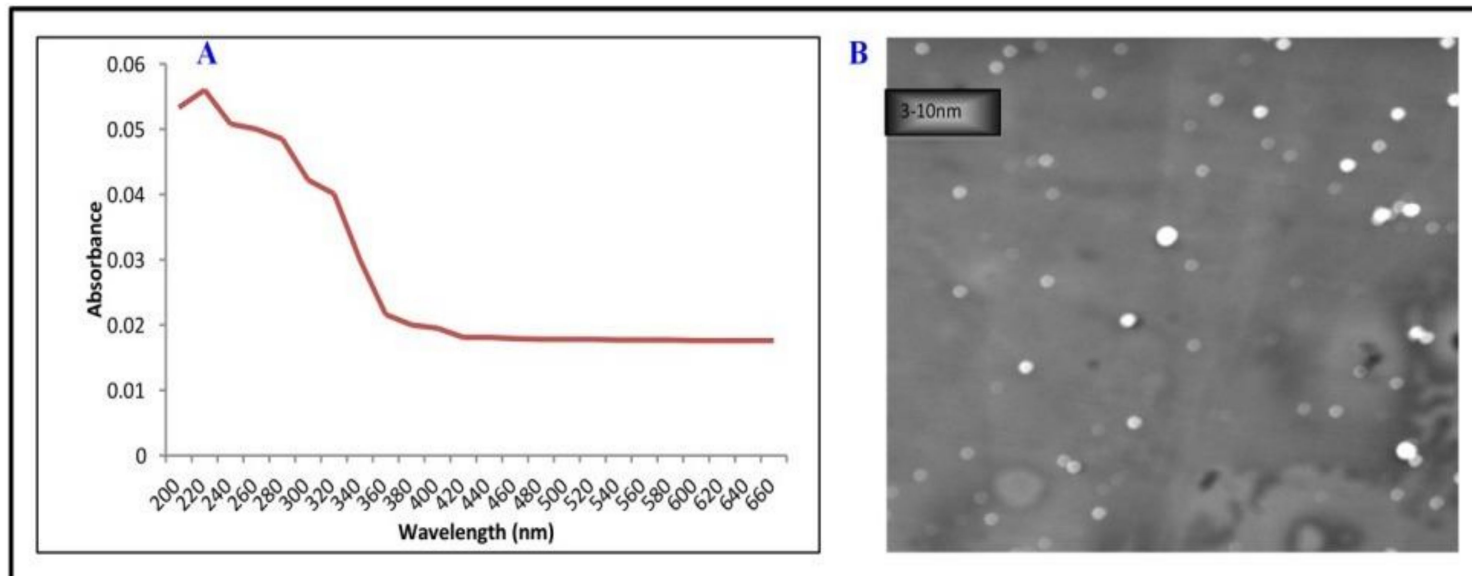

Figure 1. Physio-chemical characterization of synthesized carbon nanoparticles (CNPs) (A) UV-Vis Spectroscopy, (B) Scanning electron microscope (SEM) of CNPs with an average diameter of $6.5 \mathrm{~nm}$.

\subsection{Effect of CNPs on Growth Parameters, Photosynthetic Pigment and Protein Content}

Growth parameters, mainly plant height and biomass in the present study, were considered as primary indicators to assess the effect of nanoparticles on crop development. To infer the impact of CNPs on Vigna radiata, seedlings were exposed to nanoparticles for $96 \mathrm{~h}$ under controlled conditions in liquid medium. As shown in Figure 2B, both root and shoot length remained constant at initial concentrations, until $75 \mu \mathrm{M}$, but a minute increase was recorded at $100 \mu \mathrm{M}$, which again decreased at a higher concentration $(200 \mu \mathrm{M})$. At $100 \mu \mathrm{M}$ CNPs treatment, $16.65 \%$ and $5.67 \%$ increases in shoot and root lengths were observed (Figure 2B). Biomass of seedlings subjected to CNPs for $96 \mathrm{~h}$ increased until $100 \mu \mathrm{M}$, and a significant reduction was observed at elevated concentrations (150 and $200 \mu \mathrm{M})$. The fresh and dry weight maximums were recorded at $100 \mu \mathrm{M}$, which were about 1.20 and 1.14 times higher than the control (Figure 2A). Moreover, a similar pattern of results was observed for tolerance index (TI) and leaf water content (LWC), which were noted to rise with improved dosage of carbon nanoparticles up to $100 \mu \mathrm{M}$ and then decline with a subsequent rise in dosage. The maximum values of TI and LWC were recorded at the $100 \mu \mathrm{M}$ treatment, which were 1.26 and 1.12 times higher than the control (Figure 2C).

The chlorophyll content in the present study increased progressively with the increase in CNPs concentration up to $100 \mu \mathrm{M}$, and further, a slight decrease was recorded at higher concentrations (150 and $200 \mu \mathrm{M})$. The maximum chlorophyll content was documented at $100 \mu \mathrm{M}$, which was 1.9 times higher than untreated crops (Figure 2D). The protein content in leaves of $V$. radiata after $96 \mathrm{~h}$ of CNPs treatment showed a noticeable increase at $25 \mu \mathrm{M}$, whereas at other concentrations, the protein content increase was statistically indistinguishable as compared to that of the control. No significant change was recorded in roots when exposed to varying concentrations of CNPs (Figure 2E). 


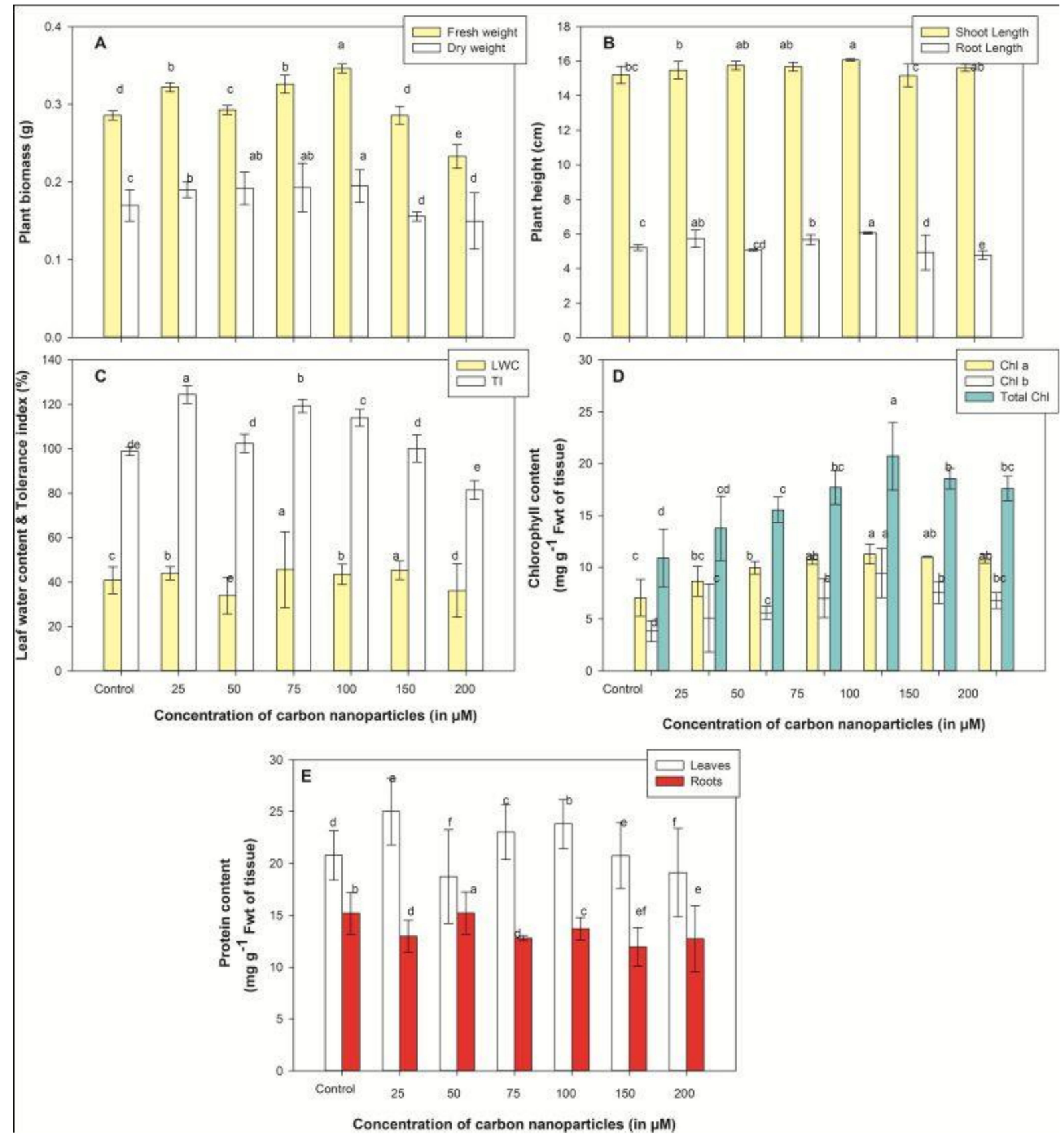

Figure 2. Plant biomass (A), plant height (B), leaf water content and tolerance index (C), chlorophyll concentration (D) and protein content $(\mathbf{E})$ in seedlings of $V$. radiata treated with various concentrations of CNPs, ranging from 25 to $200 \mu \mathrm{M}$. Values are mean \pm standard deviation $(n=3)$ and are statistically significant according to the DMRT test $(p<0.05)$. Data points marked with the same letters show insignificant differences $(p<0.05)$ within treatments.

\subsection{Effect of CNPs on Stress Parameters}

Oxidative damage was determined by estimating the amount of hydrogen peroxide and malondialdehyde (MDA) production [28]. In the present work, MDA content was recorded to decline with improved dosage of CNPs up to $100 \mu \mathrm{M}$ in both tissues. A progressive rise was documented at the $150 \mu \mathrm{M}$ dosage, which was 1.09 (leaves) and 1.06 (roots) times higher than untreated seedlings. Further elevated concentrations of $\mathrm{CNPs}$ resulted in insignificant changes in MDA content (Figure 3A). The improved level of $\mathrm{H}_{2} \mathrm{O}_{2}$ was mostly documented in root tissue of CNP-exposed seedlings (Figure 3B). The $\mathrm{H}_{2} \mathrm{O}_{2}$ content initially increased $(25 \mu \mathrm{M})$ and then remained constant until $100 \mu \mathrm{M}$, but 
a significant increase from $7.9 \%(100 \mu \mathrm{M})$ to $15.3 \%(150 \mu \mathrm{M})$ over a period of 4 days was recorded in roots. Whereas in leaves, a progressive increase in $\mathrm{H}_{2} \mathrm{O}_{2}$ content, $17.24 \%$ (from 25 to $50 \mu \mathrm{M}$ ), was observed, which gradually decreased thereafter with further increases in the concentration of CNPs (Figure 3B).
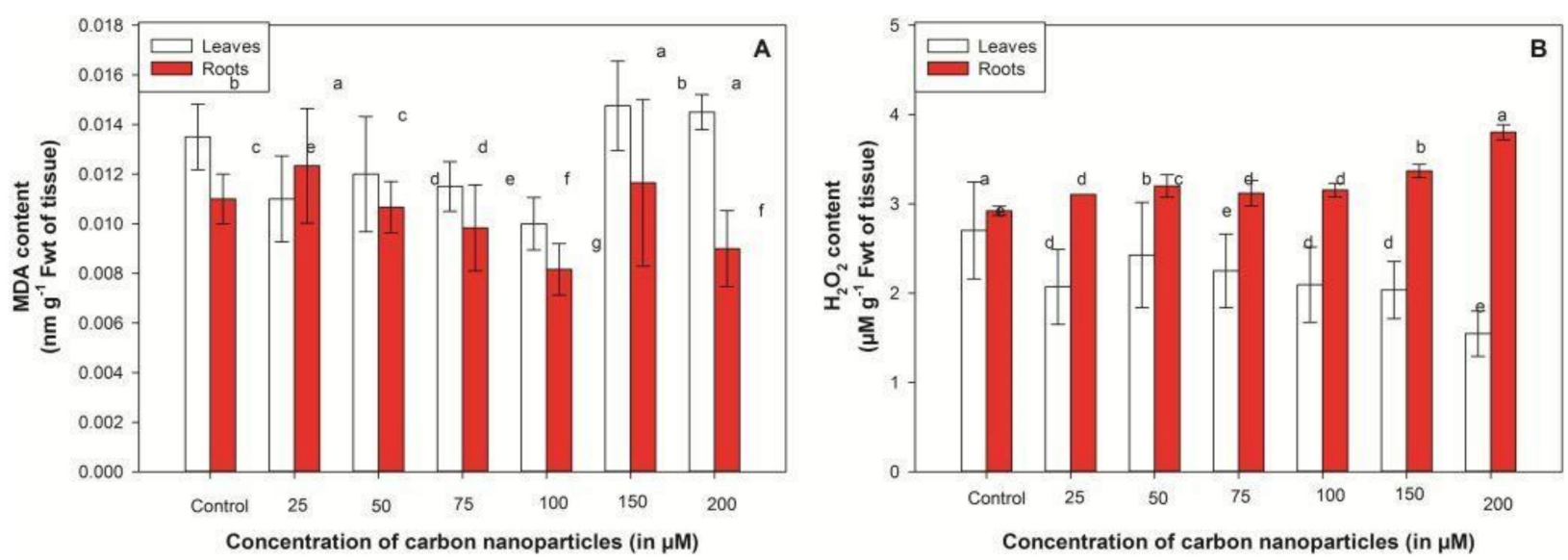

Figure 3. Effect of CNPs on MDA (A) and ROS formation $\left(\mathrm{H}_{2} \mathrm{O}_{2}\right.$ production) (B) in Vigna radiata seedlings. Seedlings were treated with 25, 50, 75, 100, 125, 150 and $200 \mu \mathrm{M}$ CNPs for a period of $96 \mathrm{~h}$. Values are mean \pm standard deviation $(n=3)$ and are statistically significant according to the DMRT test $(p<0.05)$. Data points marked with different letters show significant differences $(p<0.05)$ within treatments.

\subsection{CNPs Effect on Proline Accretion}

Accretion of proline is the common physiological alterations in plant cells subjected to changing environmental conditions. In the present study, improved amounts of proline were recorded in CNP-exposed plants compared to untreated ones, as specified in Figure $4 \mathrm{~A}$. There was a noticeable rise in the amount of proline with the increase in treatment of CNPs up to $100 \mu \mathrm{M}$. After this concentration, proline content gradually decreased with subsequent rises in dosage. The greatest accumulation of proline was recorded at $100 \mu \mathrm{M}$ CNPs, which were 1.48 (leaves) and 6.29 (roots) times higher than in untreated seedlings (Figure 4A).

\subsection{Impact of CNPs on the Activity of Antioxidant Enzymes}

Superoxide dismutase (SOD) activity was found to decrease at the initial concentration of CNPs $(25 \mu \mathrm{M})$ in both tissues. Further increases in concentration resulted in insignificant changes in SOD activity. However, no noticeable change in SOD activity was recorded until $100 \mu \mathrm{M}$ concentration, but a progressive increase $(44 \%$ more than $100 \mu \mathrm{M})$ was observed at $150 \mu \mathrm{M}$ concentration in roots (Figure 4B). Improved catalysis of superoxide dismutase, with a rise in CNPs dosage, possibly signifies the augmented level of reactive oxygen species that leads to the rise in expression of the SOD gene [29].

Ascorbate peroxidase (APX) neutralizes reactive oxygen species by catalyzing the conversion of hydrogen peroxide into water by accepting electrons from ascorbate [30]. In a recent study, APX activity was recorded more in roots than foliar tissues. APX activity increased with the increase in CNPs treatment up to $100 \mu \mathrm{M}$, and then declined with the subsequent rise in dosage in leaves. At $100 \mu \mathrm{M}$, a 56.03\% increase in catalysis of ascorbate peroxidase was noted in comparison to untreated seedlings in leaves (Figure 4C). 

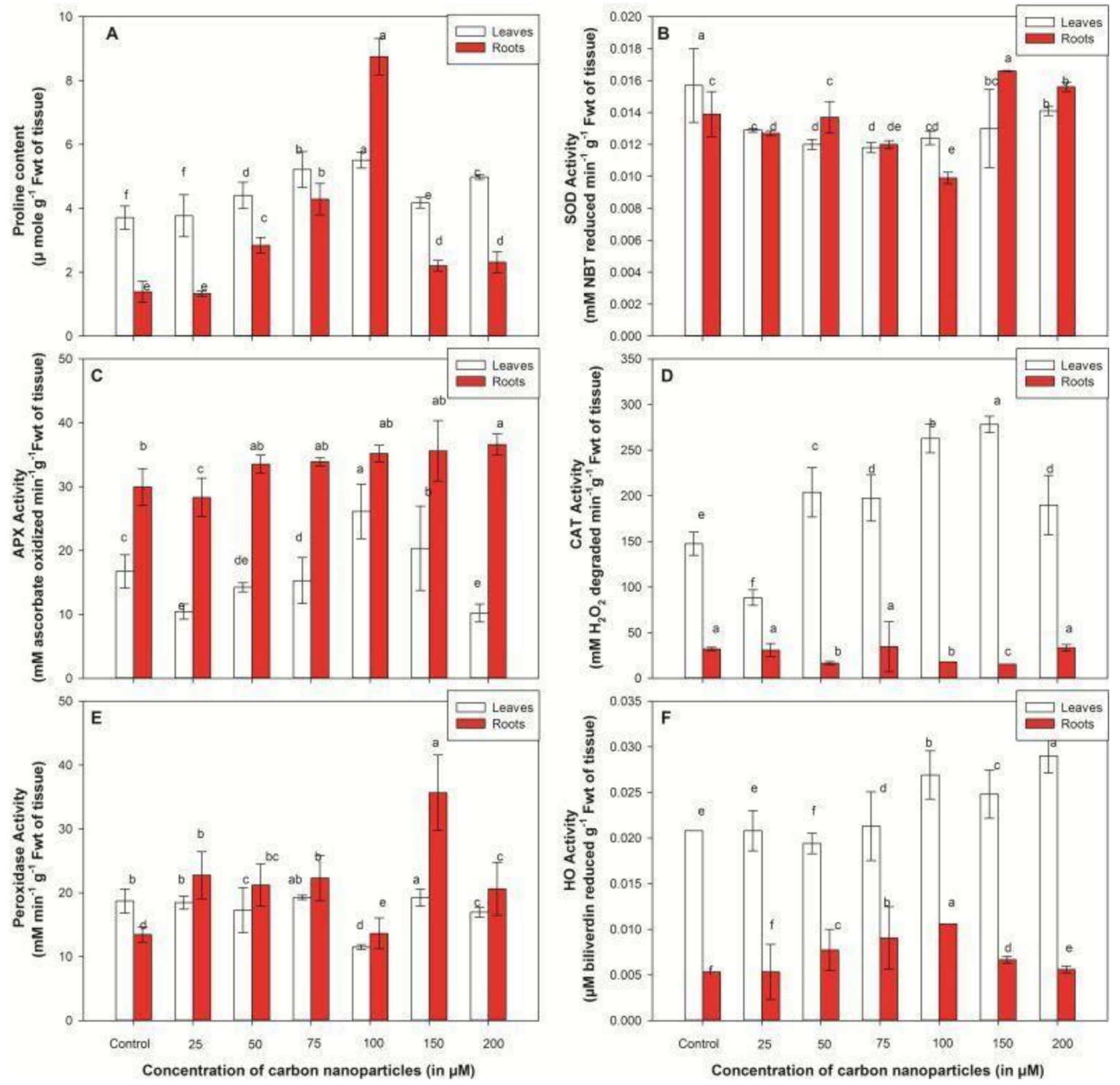

Figure 4. Effect of carbon nanoparticles on proline content (A), SOD activity (B), APX activity (C), CAT activity (D), peroxidase activity (E) and HO activity (F) in Vigna radiata seedlings at various treatments, ranging from 25 to $200 \mu \mathrm{M}$. Values are mean \pm SD of three replicates $(n=3)$ and are statistically significant according to DMRT test $(p<0.05)$. Data points marked with the same letters show insignificant differences $(p<0.05)$ within treatments.

The catalytic reaction of catalase was greater in leaves than roots (Figure 4D). In leaves, an improved CAT reaction was documented with elevated concentrations of CNPs until $150 \mu \mathrm{M}$, which then declined with the subsequent rise in dosage. A noticeable increase in enzyme activity was noted at $100 \mu \mathrm{M}$, which was 1.78 times higher than in untreated seedlings in leaves.

GOPX, the other ROS scavenging enzyme, is distinguished from APX based on substrate utilization (GOPX utilizes guaiacol while APX utilizes ascorbate as a substrate), and differences in sequences and physiological functions [30]. The catalytic reaction of GOPX was mostly observed in roots compared to leaves. The improved GOPX catalysis was noted with the rise in CNPs dosage up to $75 \mu \mathrm{M}$, and then declined at $100 \mu \mathrm{M}$. A substantial rise in GOPX activity was documented at $150 \mu \mathrm{M}$ CNPs treatment (2.65 times higher than control), which again decreased at elevated concentrations (Figure 4E). 
Heme-oxygenase activity in the current study increased with the improved dosage of CNPs from standard to $100 \mu \mathrm{M}$, and further decreased in both tissues (leaves and roots). The threshold value of $\mathrm{HO}$ catalysis was documented at $100 \mu \mathrm{M}$, which was 1.29 (leaves) and 1.17 (roots) times higher than untreated seedlings (Figure 4F).

\section{Discussion}

Carbon nanoparticles (CNPs) are composed of pure carbon and show high stability, superior conductivity (both electrical and heat), high mechanical properties, environmental friendliness and low toxicity [31], and hence their usage in agriculture to increase the yield and production of crop plants is significant to feed the growing population [32]. In the present study, an attempt has been made to understand the importance of carbon nanoparticles in some of the vital physiological processes of plants by using Vigna radiata as a plant model. The results demonstrated that interaction of CNPs with $V$. radiata seedlings causes several morpho-physiological changes in crop plants, depending on the physiochemical properties of CNPs. Since the effect of NPs on plant tissues and their ability to penetrate them strongly depend on the physiochemical characters of NPs [3], hence the characterization of engineered CNPs is important. The UV-Vis characterization verified that CNPs possess an absorption spectrum at around $215 \mathrm{~nm}$, which might originate due to $\pi \rightarrow \pi^{*}$ activation of aromatic carbons on the carbon core, while the SEM image shows agglomeration and the spherical nature of CNPs with an average diameter of $6.5 \mathrm{~nm}$ (Figure 1B). The minute size of CNPs increases their penetration into the plant tissues as the penetration totally depends on the size and concentration of CNPs [32].

Improved CNPs penetration is the key for growth of plants [32]. In the current study, the optimum concentration of CNPs which favors plant growth is $100 \mu \mathrm{M}$, where all the growth parameters were found to be higher (Figure 2A,B). Further increases in CNPs treatment result in an overall reduction in plant growth. These outcomes were in accordance with the study conducted by Li et al. [17], which shows a dose-response effect of fluorescent carbon dots on the morphology (crop height and weight) of $V$. radiata. The study showed that shoot and root length increased up to a concentration of $0.4 \mathrm{mg} / \mathrm{mL}$ of fluorescent carbon dots and further declined at higher concentrations [17]. The improved growth in $V$. radiata seedlings at $100 \mu \mathrm{M}$ CNPs is due to the fact that CNPs application increases the nitrogen and potassium content in plant organs, which is beneficial for the growth [33]. Similar enhancements in growth rate due to increases in $\mathrm{N}$ and $\mathrm{K}$ content were recorded in N. tabaccum and T. aestivum subjected to variable concentrations of CNPs, which were significantly higher in comparison to the growth obtained by the use of conventional fertilizers $[6,33]$. The decline in crop growth at a higher concentration $(200 \mu \mathrm{M})$ might be due to the accumulation of carbon nanoparticles on the roots as they are directly associated with nanoparticles which restrain the uptake of minerals by the crop, and hence limit the plant growth at improved CNPs concentration $(200 \mu \mathrm{M})$ [34].

Besides plant growth, the impact of CNPs dosage on crops is mainly reflected in the alterations in photosynthetic pigments, as chlorophyll content is regarded as one of the significant determinants of plant growth and is used as an indicator of nanoparticles' toxicity to plants [34]. In our study, the chlorophyll content of treated Vigna radiata seedlings was higher at almost all concentrations, suggesting that CNPs facilitate chlorophyll biosynthesis. A similar study conducted by Wang et al. [35] demonstrated an enhancement in the photosynthetic process by carbon dots in mung bean sprouts. He illustrated that chlorophyll content was improved by $14.8 \%$ in treated crops compared to the standard. This is probably due to the fact that carbon nanoparticles enhance the photosystem activity (Rubisco activity and chlorophyll content) by accelerating the electron transfer rate [35]. In another study, a significant improvement in chlorophyll content (46.4\%) and leaf protein (96\%) was observed in Vigna radiata by an application of $\mathrm{TiO}_{2} \mathrm{NPs}_{\text {[36] }}$. However, the minute decline in chlorophyll concentration at improved dosages (150 and $200 \mu \mathrm{M}$ CNPs) might be due to the yellowing of leaves in CNP-exposed crops, compared to untreated crops [18]. Oxidative damage takes place in the cell's plastid due to the probable association of ENPs 
with the chloroplast, that ultimately results in disruption of chlorophyll biosynthesis or causes chlorophyll reduction in leaves at higher CNPs concentrations [34].

Protein content initially increased in the leaves with increasing concentration of CNPs in the nutrient media and decreased at higher concentrations (Figure 2E). Elevated protein content at low CNPs concentration is recognized in the stimulation of stress proteins [10]. The comparable study with ZnO NPs conducted by Raliya and Tarafdar [37] on Cyamopsis tetragonoloba demonstrated that $\mathrm{ZnO} \mathrm{NPs}$ enhanced the root area $(73.5 \%)$, root length $(66.3 \%)$, shoot length $(31.5 \%)$, plant biomass $(27.1 \%)$, total protein $(27.1 \%)$ and chlorophyll content $(276.2 \%)$.

Carbon nanoparticles treatment at a higher concentration $(200 \mu \mathrm{M})$ in the liquid medium increases toxic effects in plants. The toxicity mechanisms of engineered nanoparticles are not known, and therefore production of $\operatorname{ROS}\left(\mathrm{H}_{2} \mathrm{O}_{2}, \mathrm{OH}^{-}, \mathrm{O}_{2}^{-}\right.$and $\left.\mathrm{O}_{2}{ }^{-2}\right)$ and oxidative damage were regarded as indicators to explicate the phytotoxic effect of CNPs [18]. Hydrogen peroxide is an important element that controls the defense mechanisms, acclimatory processes, metabolic processes and gene expression in plants. It is the most stable form of ROS and therefore plays a vital role as a signaling molecule in various physiological processes [18]. An increase in $\mathrm{H}_{2} \mathrm{O}_{2}$ content was recorded at the initial CNPs treatment $(25 \mu \mathrm{M})$, which decreased with the rise in concentration up to $100 \mu \mathrm{M}$ and again increased at elevated treatments (150-200 $\mu \mathrm{M})$ (Figure 3B). Augmented generation of $\mathrm{H}_{2} \mathrm{O}_{2}$ leads to the surplus production of malondialdehyde [38]. The outcome of the study indicated the decline in MDA content in seedlings of $V$. radiata with the increase in CNPs concentration up to $100 \mu \mathrm{M}$. Comparable outcomes were noticed in maize seedlings exposed to $\mathrm{TiO}_{2}$ and $\mathrm{SiO}_{2} \mathrm{NPs}$, in which MDA content significantly decreased with the rise in nanoparticle concentration [34]. Contradictory results of lipid peroxidation were recorded in Brassica juncea treated with zinc oxide nanoparticles [18], CuO NP-treated chickpea [39] and Indian mustard seedlings [40], where MDA content progressively increased with the increase in concentration of nanoparticles (from 200 to $1000 \mathrm{mg} / \mathrm{L}$ ). The reduction in oxidative damage at $100 \mu \mathrm{M}$ concentration might be due to the small size of CNPs $(3-10 \mathrm{~nm})$, which have a higher penetration ability and can easily penetrate in plant organs and increase the nutrient absorption and nutrient flow. The increased intracellular nutrient content increases the tolerance as well as adaptation ability of plants in different environmental conditions, and thereby decreases the oxidative damage (MDA and $\mathrm{H}_{2} \mathrm{O}_{2}$ content) [3]. Moreover, the cell wall acts as a preliminary barrier for the penetration of nanoparticles into the plant cell. Parallel outcomes were reported in maize seedlings, where $\mathrm{TiO}_{2} \mathrm{NPs}$ were only recorded on the surface of leaves and no cellular penetration of nanoparticles was noticed [34]. A progressive increase in MDA and $\mathrm{H}_{2} \mathrm{O}_{2}$ content after $100 \mu \mathrm{M}$ CNPs treatment indicates that CNPs mediated oxidative stress induction at higher concentrations. Similar results were verified in Oryza sativa exposed to $\mathrm{CuO}$ nanoparticles [41]. The direct association of plant cells with copper oxide nanoparticles or surplus copper ions results in the improved production of reactive oxygen species and malondialdehyde in Brassica juncea [40].

The contradictory results of lipid peroxidation and proline with the increase in CNPs dosage in the study indicate a linear relation between the formation of reactive oxygen species (hydrogen peroxide) and its mitigation via proline. Besides operating as an osmolyte, proline also work as a scavenger that quenches the metal ions and reactive oxygen species intermediates (hydroxyl radicals and singlet oxygen) and confers a shield towards stress-stimulated cell destruction $[18,40]$. Increased proline amount with elevated CNPs concentration specifies the change in membrane permeability, resulting in water stress that finally leads to higher proline content. Proline accumulation in the present work was comparable with the preceding reports on diverse crops with different environmental conditions $[10,29,42-45]$.

Disproportion in reactive oxygen species metabolism is the principal cause of plant cell damage. CAT, GOPX, APX, SOD and HO are the chief antioxidant enzymes that guard biological cells by eradicating hydrogen peroxide and other ROS [46]. During reactive oxygen species detoxification, the preliminary reaction was initiated by superoxide dismu- 
tase, which provides defense against the toxic effects of ROS by deactivating superoxide radicals into $\mathrm{H}_{2} \mathrm{O}_{2}$ and $\mathrm{O}_{2}$ [47]. $\mathrm{H}_{2} \mathrm{O}_{2}$ generated by the superoxide dismutase activity was subsequently reduced to $\mathrm{H}_{2} \mathrm{O}$ by utilizing other enzymes such as GOPX, APX and CAT [10]. In our study, the activity of all antioxidants, including SOD, CAT, POD, APX and HO, increased under CNPs treatment, which shows the clear response of $V$. radiata seedlings towards carbon nanoparticles, although the decrease in enzyme activity at $200 \mu \mathrm{M}$ might be due to the phytotoxic effect of CNPs on protein formation and other physiological parameters at high concentrations that inhibit enzyme proteins [18]. Similar trends in antioxidant activity were recorded in Brassica juncea and Brassica nigra treated with $\mathrm{ZnO}$ [18] and Ag nanoparticles [48]. Moreover, we observed dissimilar antioxidant activity in our study, such as increased activity of peroxidases (GOPX and APX) in roots and CAT in leaves after exposure of CNPs treatment for a period of $96 \mathrm{~h}$. The difference in antioxidant activity in crop tissues demonstrates that these antioxidants were working in parallel to exterminate hydrogen peroxide. The insignificant activity of catalase in roots was indemnified by the improved catalysis of peroxidases. Peroxidase has stronger reactivity for hydrogen peroxide (in $\mu \mathrm{M}$ range) than catalase ( $\mathrm{mM}$ range) and plays a significant function in neutralizing ROS under a changing environment [49]. Moreover, catalase is reactive towards superoxide radicals, and hence their growing amount at higher CNPs treatment may result in the inactivation of enzymes [50]. The reduction in enzymes' activity might also be associated with damage by peroxisomal proteases or probably due to inactivation of antioxidants [51].

Exposure of CNPs on plants and their interaction causes several physiological changes in the plant species, which depend on the properties of CNPs such as shape, size, dosage, reactivity, surface covering, type and chemical composition. The efficiency of particular types of CNPs varies with the plant, and the effect (either beneficial or adverse) of the CNPs-plant interaction, is always concentration-dependent [3]. In our study, intermediate concentrations $(100 \mu \mathrm{M})$ of CNPs enhanced the growth of $V$. radiata by increasing plant biomass, chlorophyll content, augmentation of antioxidants and lowering the oxidative damage. This might be due to the higher penetration of CNPs, which is inversely proportional to size and is the key factor behind improved growth. The carbon nanoparticles are taken-up by plants from the liquid medium via roots and distributed in the aerial parts through capillary action [52]. The absorption and distribution of CNPs into the plant system results in remarkable changes in metabolic functions, including increasing water uptake (by inducing expression of gene-encoding water channel proteins or by cell wall pores), and enhancing nutrient (Fe, $\mathrm{Mg}, \mathrm{Ca}$ and $\mathrm{K}$ ) absorption, leading to an increase in plant biomass and improved physiological activity [52] (Figure 5). Treatment with ENPs at higher concentrations (above $100 \mu \mathrm{M}$ ) might increase the amounts of nanoparticles in crop tissues, which seem to cross the bio-membrane and assemble to form clumps with their own particles or with biomaterials present inside the cell [53]. This might create a disturbance in the cellular compartment and increase the hydroxyl radical or other forms of ROS inside the cell, which finally results in an increase in the activity of antioxidants. The activated antioxidant mechanisms control and establish the redox balance, but at elevated concentrations $(200 \mu \mathrm{M})$, biochemical effects do occur. Elevated concentration of all the antioxidant molecules is the possible reason for the high tolerance level exhibited by $V$. radiata to CNPs. Moreover, at elevated treatment $(200 \mu \mathrm{M})$, higher CNPs concentrations might accumulate in the plant tissues and block the passage for nutrients to flow further, and thus hamper the plant growth [52]. 


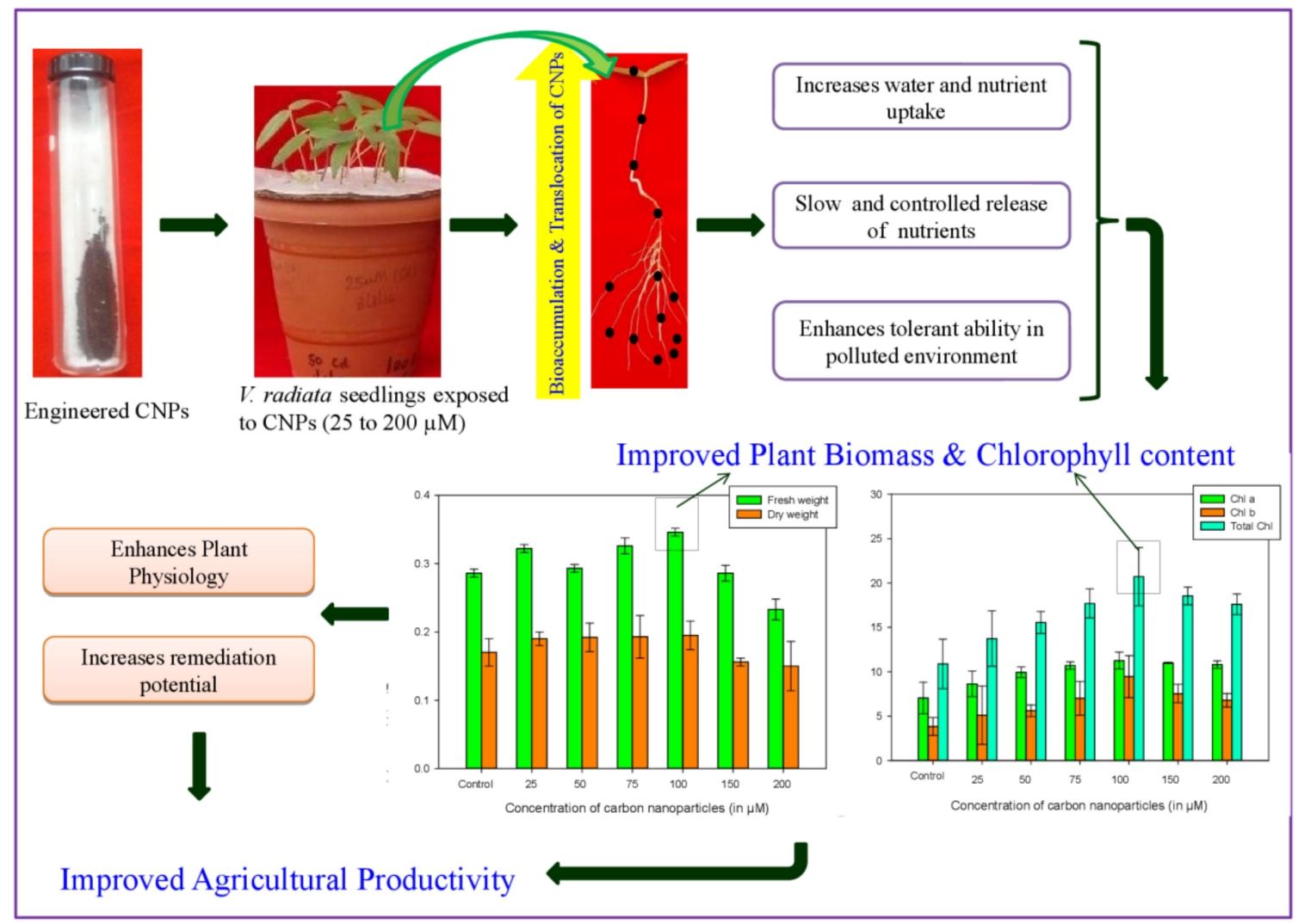

Figure 5. Schematic representation of the role of carbon nanoparticles (CNPs) in improving agricultural productivity of crop plants.

\section{Materials and Methods}

\subsection{Carbon Nanoparticles (CNPs): Synthesis and Characterization}

Carbon nanoparticles (CNPs) were synthesized by the microwave-assisted method [54]. Sucrose solution (in water) was mixed with ortho-phosphoric acid $(88 \% v / v)$ by heating it in a microwave for 5 to $15 \mathrm{~min}$. When the color of the solution changed from yellow to brownish black, distilled water was added to it after cooling. To obtain the carbon nanoparticles (CNPs), the solution was centrifuged for $10 \mathrm{~min}$ at $4000 \times \mathrm{g}$. The procured CNPs precipitates were washed 5 to 6 times with deionized water, followed by centrifugation to remove the remaining traces of acid. The purified CNPs were filtered on Whatman filter paper No. 1. The filter papers containing CNPs were dehydrated overnight in an oven. After drying, nanoparticles were scraped out and stored in an air-tight container (Figure 6). The nanoparticles were dispersed in distilled water $(\mathrm{pH} \geq 7)$ for further use [54]. The CNPs were characterized using a UV-Visible spectrophotometer to determine the optical properties of a solution. For examination of nanoparticles, a $1 \mathrm{mM}$ solution of carbon nanoparticles was prepared and analyzed for the wavelength from 200 to $650 \mathrm{~nm}$. Moreover, the morphology, dimension and structure of CNPs were determined using a scanning electron microscope. 


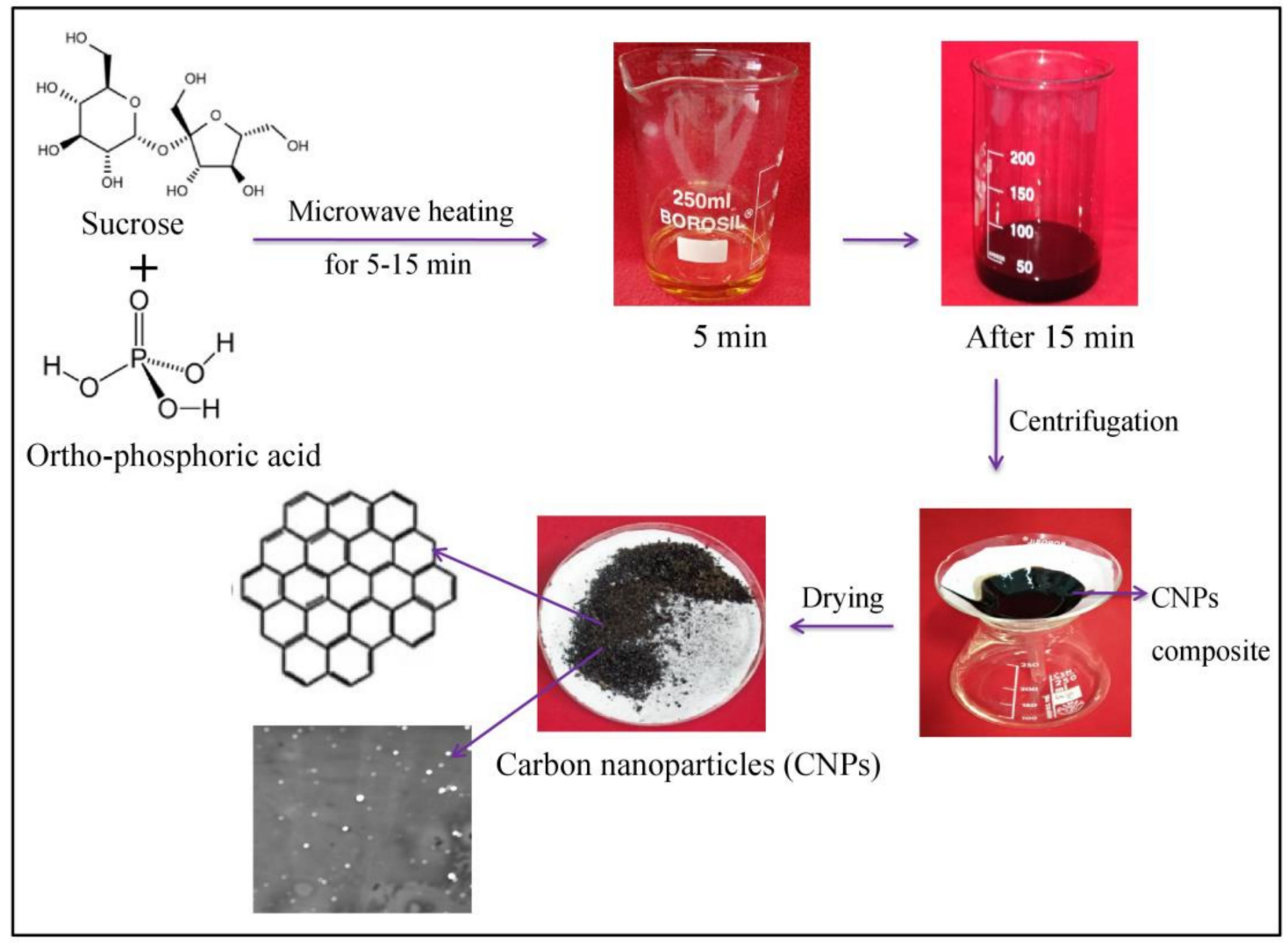

Figure 6. Representation of the mechanism of synthesis of carbon nanoparticles (CNPs) by heating sucrose solution and ortho-phosphoric acid.

\subsection{Plant Cultivation}

Vigna radiata var. PDM 54 seeds were obtained from NBPGR, Jodhpur, India, and stored in an air-tight container. Before use, the seeds were disinfected with $0.1 \% \mathrm{HgCl}_{2}$ for thirty seconds to one minute to avoid contamination, and cleansed three to four times with deionized water to make sure they were free from any traces of mercuric chloride. These seeds were then germinated in a sterile environment in a seed germinator at $25^{\circ} \mathrm{C}$ in the dark. After germination, identical $V$. radiata seedlings were transferred to pots $\left(12 \times 12 \mathrm{~cm}^{2}\right)$ containing Hoagland nutrient solution ( $\mathrm{pH} 6.8$ to 6.9 ) and placed at $25 \pm 2{ }^{\circ} \mathrm{C}, 50 \%$ relative humidity, to set-up the liquid culture. The liquid medium was aerated twice daily to avoid inadequate supply of oxygen and prevent precipitation of salts. The nutrient medium was replaced every alternate day to circumvent nutrient deficiencies.

\subsection{Carbon Nanoparticles Treatment}

After seven days, acclimatized $V$. radiata seedlings in liquid medium were exposed to CNPs at different dosages, from 25 to $200 \mu \mathrm{M}(25,50,75,100,150$ and $200 \mu \mathrm{M})$. A nutrient medium without CNPs was regarded as the control and utilized to evaluate the effect of CNPs on crops. After $96 \mathrm{~h}$, seedlings of uniform size were harvested for the analysis of several morphological and physiological characteristics [10].

\subsection{Growth Analysis}

For growth parameter studies, freshly harvested crop seedlings were cleansed with deionized water and roots were separated from aerial tissue. Growth of the crops was analyzed by measuring plant height (root and shoot length), biomass (fresh and dry weight), leaf water content and tolerance index. Plant height of both treated and control seedlings was measured in centimeters. To determine the dry weight, fresh seedlings were desiccated at $65{ }^{\circ} \mathrm{C}$ overnight in an oven, and the weight of dehydrated seedlings was 
measured. The water content of the leaves was computed by the equation: (fresh weight dry weight)/fresh weight $\times 100$. Tolerance index was calculated according to the method of Wilkins [55] and expressed in percentage.

\subsection{Estimation of Photosynthetic Pigment and Protein Content}

Chlorophyll contents (chlorophyll a, b and total chlorophyll) were estimated by Arnon's [56] method. Fresh leaves of the seedlings were pulverized in chilled acetone $(80 \%$ $v / v)$. Grounded samples were centrifuged in cold conditions for $15 \mathrm{~min}$ at $10,000 \times g$. The amount of chlorophyll ( $\mathrm{mg} \mathrm{g}^{-1}$ fresh weight of leaves) was computed from the optical density of the supernatant recorded at 663 and $645 \mathrm{~nm}$ [56].

Protein content was determined via Lowry et al.'s [57] method. Freshly harvested tissue was ground in sodium phosphate buffer $(50 \mathrm{mM}, \mathrm{pH}$ 7.0). The procured supernatant after centrifugation (at $4{ }^{\circ} \mathrm{C}$ for $10 \mathrm{~min}$ at $10,000 \times \mathrm{g}$ ) was reacted with an assay mixture $\left(\mathrm{Na}_{2} \mathrm{CO}_{3}(2 \% w / v)\right.$ in $\left.\mathrm{NaOH}(0.1 \mathrm{~N})+\mathrm{CuSO}_{4} \cdot 5 \mathrm{H}_{2} \mathrm{O}(0.5 \% w / v)+\mathrm{KNaC}_{4} \mathrm{H}_{4} \mathrm{O}_{6} \cdot 4 \mathrm{H}_{2} \mathrm{O}(1 \%)\right)$ at room temperature for $10 \mathrm{~min}$. After incubation, Folin-Ciocalteu reagent was incorporated in the above reaction mixture. The optical density of the blue color complex formed after $30 \mathrm{~min}$ of incubation was noted at $660 \mathrm{~nm}$. The protein content $\left(\mathrm{mg} \mathrm{g}^{-1}\right.$ fresh weight of tissue) was computed from the linear curve prepared by utilizing bovine serum albumin (BSA) as a control.

\subsection{Determination of Stress Parameters (Lipid Peroxidation and $\mathrm{H}_{2} \mathrm{O}_{2}$ Content)}

Peroxidation of lipid was estimated by De Vos et al.'s [58] protocol by measuring the amount of malondialdehyde (MDA). Plant tissue was crushed in 2-thiobarbituric acid $(0.25 \% w / v)$ made in trichloroacetic acid $(10 \% v / v)$. The sample was reacted for half an hour in a water bath and further brought to room temperature to cease the reaction. The reacted sample was centrifuged for $10 \mathrm{~min}$ at $3000 \times \mathrm{g}$. The amount of peroxidation of lipid (nm g ${ }^{-1}$ fresh weight of tissue) was calculated from the specific absorbance $\left(\lambda_{532}-\lambda_{600}\right)$ by utilizing $155 \mathrm{mM}^{-1} \mathrm{~cm}^{-1}$ as the molar absorption coefficient.

$\mathrm{H}_{2} \mathrm{O}_{2}$ content in crop seedlings was studied spectrophotometrically by Alexivea et al.'s [59] method. Fresh plant tissue, homogenized in trichloroacetic acid $(0.1 \% w / v)$ in cold conditions, was centrifuged for $15 \mathrm{~min}$ at $10,000 \times \mathrm{g}$. Absorbance of the supernatant reacted with $\mathrm{KPO}_{4}$ buffer $(10 \mathrm{mM}, \mathrm{pH} 7)$ and $\mathrm{KI}(1 \mathrm{M})$ for an hour in the dark was documented at $390 \mathrm{~nm}$. $\mathrm{H}_{2} \mathrm{O}_{2}$ level was estimated by utilizing $0.28 \mu \mathrm{M}^{-1} \mathrm{~cm}^{-1}$ as the proportionality coefficient.

\subsection{Antioxidative Response Evaluation}

Proline content was estimated according to Bates et al.'s [60] protocol. Fresh tissue homogenized in sulfosalicylic acid $(3 \% w / v)$ was centrifuged for $20 \mathrm{~min}$ at $3000 \times g$. The procured supernatant was incubated with equal volumes of ninhydrin solution and glacial acetic acid at $100{ }^{\circ} \mathrm{C}$ for an hour and immediately transferred on ice. Absorbance of the colored organic layer obtained by the addition of toluene to the cooled reaction mixture was documented at $520 \mathrm{~nm}$. The amount of proline ( $\mu \mathrm{g} \mathrm{g}^{-1}$ fresh weight of tissue) was computed from a linear graph made by L-proline.

\subsection{Enzymatic Assay}

Fresh plant tissue homogenized in $\mathrm{NaPO}_{4}$ buffer $(50 \mathrm{mM}, \mathrm{pH}$ 7) was centrifuged at $4{ }^{\circ} \mathrm{C}$ for $20 \mathrm{~min}$ at $5000 \times \mathrm{g}$. The supernatant obtained was utilized for the enzymatic assay.

Ascorbate peroxidase (APX) activity was assayed according to Chen and Asada's [61] protocol. The rate of oxidation of ascorbic acid was documented by the decline in optical density of the assay mixture $\left(\mathrm{NaPO}_{4}\right.$ buffer $50 \mathrm{mM}, \mathrm{pH} 7$, having ascorbic acid $(0.6 \mathrm{mM})+$ hydrogen peroxide $(10 \% v / v)+$ enzyme extract) at $290 \mathrm{~nm}$ by utilizing $2.8 \mathrm{mM}^{-1} \mathrm{~cm}^{-1}$ as the proportionality constant [61].

The catalytic reaction of catalase (CAT) was analyzed via Aebi's [62] procedure. The degradation rate of hydrogen peroxide was noted by the decline in optical density of the 
reaction compound $\left(\mathrm{NaPO}_{4}\right.$ buffer $50 \mathrm{mM}, \mathrm{pH} 7$ + hydrogen peroxide $(9 \mathrm{mM})+$ enzyme extract) at $240 \mathrm{~nm}$ by inserting $0.039 \mathrm{mM}^{-1} \mathrm{~cm}^{-1}$ as the proportionality constant [62].

The guaiacol peroxidase (GOPX) catalytic reaction was evaluated by documenting the rise in optical density of the assay compound $\left(\mathrm{NaPO}_{4}\right.$ buffer $50 \mathrm{mM}+$ hydrogen peroxide $(3.7 \mathrm{mM})+$ guaiacol $(20 \mathrm{mM})+$ enzyme extract) at $436 \mathrm{~nm}$ (molar absorption coefficient $26.6 \mathrm{mM}^{-1} \mathrm{~cm}^{-1}$ ) [63].

The catalytic reaction of superoxide dismutase (SOD) was estimated by Beauchamp and Fridovich's [64] method. The activity was assayed by recording the optical density of the assay compound $\left(\mathrm{NaPO}_{4}\right.$ buffer $50 \mathrm{mM}, \mathrm{pH} 7+\mathrm{NBT}(75 \mu \mathrm{M})+$ riboflavin $(2 \mathrm{mM})+$ methionine $(13 \mathrm{mM})+$ EDTA $(0.1 \mathrm{mM})+$ enzyme extract) at $560 \mathrm{~nm}$ after half an hour of incubation under bright light, which will quantify the capability of an enzyme to hinder the photochemical reduction of NBT (nitroblue tetrazolium) [64].

Heme-oxygenase $(\mathrm{HO})$ catalysis was assayed via Balestrasse et al.'s [65] protocol. Freshly harvested tissue homogenized in chilled buffer $\left(\mathrm{KPO}_{4}\right.$ buffer, $50 \mathrm{mM}$, pH 7.4 + EDTA $(200 \mu \mathrm{M})+$ PMSF $(1000 \mu \mathrm{M})+$ sucrose $(250 \mathrm{mM}))$ was centrifuged for $20 \mathrm{~min}$ at $20,000 \times g$ in a cold environment. The supernatant (HO extract) was reacted with NADPH $(0.06 \mu \mathrm{M})$ and hemin $(0.2 \mu \mathrm{M})$ for an hour at $37^{\circ} \mathrm{C}$, and the absorbance of the obtained product (biliverdin) (proportionality constant $6.25 \mu \mathrm{M}^{-1} \mathrm{~cm}^{-1}$ ) was recorded at $650 \mathrm{~nm}$.

\subsection{Examination of Data}

Results were statistically analyzed by SPSS 16 . Data were regarded as average ( \pm standard deviation) of independent replicas $(n=3)$. The variations between standard and concentrations were examined by utilizing one-way ANOVA (analysis of variance) at the $0.05 \%$ significance level via Duncan's multiple range test (DMRT) [10].

\section{Conclusion}

From the present work, it is concluded that CNPs at intermediate concentrations $(100-150 \mu \mathrm{M})$ favor the growth of $V$. radiata seedlings. At these concentrations, the highest activity of antioxidants (SOD, GOPX, APX and proline) were recorded, which resulted in the decline of the ROS level, and hence, the total biomass increased. At the highest treatment $(200 \mu \mathrm{M})$, the aggregation of CNPs was observed more on the root surface, as the root comes in direct contact and gets accumulated in higher concentrations in the plant tissues, which blocks the passage for nutrients and thus inhibits the uptake and translocation of nutrients to plants. Hence, the oxidative damage enforced by CNPs circumvents with the improved activity of antioxidants. The increases in biomass, total chlorophyll and protein content in CNP-treated $V$. radiata seedlings in the study are valuable from an agricultural perspective. CNPs promote nutrient absorption and accumulation amount, thus increasing the efficiency of fertilizer, which finally improves plant quality. Moreover, CNPs can greatly contribute to pollutant removal and soil remediation as they possess an enormous absorption potential due to their high surface area. Hence, CNPs could be a preferable choice as nano-fertilizers, compared to conventional fertilizers or manure, that not only improve plant growth by their slow and controlled release of nutrients, but also enhance the stress-tolerant and phytoremediation efficiency of the plant in the polluted environment.

Author Contributions: G.S.S. designed and conceptualized the study; L.M. executed the experiments, analyzed, interpreted and summarized all data and wrote the manuscript; P.R., V.D.R., T.M., R.K.S. and G.S.S. helped in statistical analysis, and reviewed and edited the manuscript. All authors have read and agreed to the published version of the manuscript.

Funding: This study was financially supported by the University Grants Commission, New Delhi, India, through the center for advanced study program, and the Russian Science Foundation, Russia. Dr. Rajput and Prof. Minkina would like to recognize the financial support by the Ministry of Science and Higher Education of the Russian Federation within the framework of the state task in the field of scientific activity No. 0852-2020-0029.

Data Availability Statement: Not applicable. 
Acknowledgments: G.S.S. is thankful to the University Grants Commission (UGC), New Delhi, India, for providing financial assistance through the center for advanced study (CAS).

Conflicts of Interest: The authors do not have any conflict of interest.

\section{References}

1. Kumar, A.; Singh, A.; Panigrahy, M.; Sahoo, P.K.; Panigrahi, K.C.S. Carbon nanoparticles influence photomorphogenesis and flowering time in Arabidopsis thaliana. Plant Cell Rep. 2018, 37, 901-912. [CrossRef] [PubMed]

2. Wang, C.; Zhang, H.; Ruan, L.; Chen, L.; Li, H.; Chang, X.-L.; Zhang, X.; Yang, S.-T. Bioaccumulation of 13C-fullerenol nanomaterials in wheat. Environ. Sci. Nano 2016, 3, 799-805. [CrossRef]

3. Verma, S.K.; Das, A.K.; Gantait, S.; Kumar, V.; Gurel, E. Applications of carbon nanomaterials in the plant system: A perspective. Sci. Total. Environ. 2019, 667, 485-499. [CrossRef] [PubMed]

4. Niazi, J.H.; Verma, S.K.; Niazi, S.; Qureshi, A. In vitro HER2 protein-induced affinity dissociation of carbon nanotube-wrapped anti-HER2 aptamers for HER2 protein detection. Analyst 2014, 140, 243-249. [CrossRef]

5. Mohajeri, M.; Behnam, B.; Sahebkar, A. Biomedical applications of carbon nanomaterials: Drug and gene delivery potentials. J. Cell. Physiol. 2019, 243, 298-319. [CrossRef]

6. Saxena, M.; Maity, S.; Sarkar, S. Carbon nanoparticles in 'biochar' boost wheat (Triticum aestivum) plant growth. RSC Adv. 2014, 4, 39948-39954. [CrossRef]

7. Yang, J.; Cao, W.; Rui, Y. Interactions between nanoparticles and plants: Phytotoxicity and defense mechanisms. J. Plant Interact. 2017, 12, 158-169. [CrossRef]

8. Mukherjee, A.; Majumdar, S.; Servin, A.D.; Pagano, L.; Dhankher, O.P.; White, J.C. Carbon Nanomaterials in Agriculture: A Critical Review. Front. Plant Sci. 2016, 7, 172. [CrossRef]

9. Rico, C.; Majumdar, S.; Duarte-Gardea, M.; Peralta-Videa, J.R.; Gardea-Torresdey, J.L. Interaction of nanoparticles with edible plants and their possible implications in the food chain. J. Agric. Food Chem. 2011, 59, 3485-3498. [CrossRef]

10. Mahawar, L.; Kumar, R.; Shekhawat, G.S. Evaluation of heme oxygenase 1 (HO 1) in Cd and Ni induced cytotoxicity and crosstalk with ROS quenching enzymes in two to four leaf stage seedlings of Vigna radiata. Protoplasma 2017, 255, 527-545. [CrossRef]

11. Mahawar, L.; Shekhawat, G.S. EsHO 1 mediated mitigation of $\mathrm{NaCl}$ induced oxidative stress and correlation between ROS, antioxidants and HO 1 in seedlings of Eruca sativa: Underutilized oil yielding crop of arid region. Physiol. Mol. Biol. Plants 2019, 25, 895-904. [CrossRef]

12. Balestrasse, K.B.; Yannarelli, G.G.; Noriega, G.O.; Batlle, A.; Tomaro, M.L. Heme oxygenase and catalase gene expression in nodules and roots of soybean plants subjected to cadmium stress. BioMetals 2008, 21, 433-441. [CrossRef]

13. Mahawar, L.; Popek, R.; Shekhawat, G.S.; Alyemeni, M.N.; Ahmad, P. Exogenous hemin improves Cd2+ tolerance and remediation potential in Vigna radiata by intensifying the HO-1 mediated antioxidant defence system. Sci. Rep. 2021, 11, 2811. [CrossRef]

14. Shekhawat, G.S.; Parihar, S.; Mahawar, L.; Khator, K.; Bulchandani, N. Bilin Metabolism in Plants: Structure, Function and Haem Oxygenase Regulation of Bilin Biosynthesis. In eLS; John Wiley \& Sons: Hoboken, NJ, USA, 2019; pp. 1-13. [CrossRef]

15. Mahawar, L.; Shekhawat, G.S. Haem oxygenase: A functionally diverse enzyme of photosynthetic organisms and its role in phytochrome chromophore biosynthesis, cellular signalling and defence mechanisms. Plant Cell Environ. 2018, 41, 483-500. [CrossRef]

16. Shekhawat, G.S.; Verma, K. Haem oxygenase (HO): An overlooked enzyme of plant metabolism and defence. J. Exp. Bot. 2010, 61, 2255-2270. [CrossRef]

17. Li, Y.; Zheng, H.; Zhang, Z.; Liu, W.; Su, S.; Chen, Y.; Liu, L.; Zhuang, J.; Lei, B. Phytotoxicity, Uptake, and Translocation of Fluorescent Carbon Dots in Mung Bean Plants. ACS Appl. Mater. Interfaces 2016, 8, 19939-19945. [CrossRef]

18. Rao, S.; Shekhawat, G. Toxicity of $\mathrm{ZnO}$ engineered nanoparticles and evaluation of their effect on growth, metabolism and tissue specific accumulation in Brassica juncea. J. Environ. Chem. Eng. 2014, 2, 105-114. [CrossRef]

19. Doshi, R.; Braida, W.; Christodoulatos, C.; Wazne, M.; O'Connor, G. Nano-aluminum: Transport through sand columns and environmental effects on plants and soil communities. Environ. Res. 2008, 106, 296-303. [CrossRef]

20. Lin, D.; Xing, B. Phytotoxicity of nanoparticles: Inhibition of seed germination and root elongation. Environ. Pollut. 2007, 150, 243-250. [CrossRef]

21. Nel, A.; Xia, T.; Mädler, L.; Li, N. Toxic Potential of Materials at the Nanolevel. Science 2006, 311, 622-627. [CrossRef]

22. Hong, F.; Zhou, J.; Liu, C.; Yang, F.; Wu, C.; Zheng, L.; Yang, P. Effect of Nano-TiO2 on Photochemical Reaction of Chloroplasts of Spinach. Biol. Trace Element Res. 2005, 105, 269-280. [CrossRef]

23. Yang, F.; Hong, F.; You, W.; Liu, C.; Gao, F.; Wu, C.; Yang, P. Influences of Nano-anatase TiO2 on the Nitrogen Metabolism of Growing Spinach. Biol. Trace Element Res. 2006, 110, 179-190. [CrossRef]

24. Lu, C.M.; Zhang, C.Y.; Wen, J.Q.; Wu, G.R.; Tao, M.X. Research of the effect of nanometer materials on germination and growth enhancement of Glycine max and its mechanism. Soybean Sci. 2002, 21, 168-172.

25. Singla, R.; Kumari, A.; Yadav, S.K. Impact of Nanomaterials on Plant Physiology and Functions. In Nanomaterials and Plant Potential; Springer Science and Business Media LLC: Berlin, Germany, 2019; pp. 349-377. [CrossRef]

26. Sumithra, K.; Jutur, P.P.; Carmel, B.D.; Reddy, A.R. Salinity-induced changes in two cultivars of Vigna radiata: Responses of antioxidative and proline metabolism. Plant Growth Regul. 2006, 50, 11-22. [CrossRef] 
27. Thomas; Robertson, M.; Fukai, S.; Peoples, M. The effect of timing and severity of water deficit on growth, development, yield accumulation and nitrogen fixation of mungbean. Field Crop. Res. 2004, 86, 67-80. [CrossRef]

28. Chung, I.-M.; Rekha, K.; Venkidasamy, B.; Thiruvengadam, M. Effect of Copper Oxide Nanoparticles on the Physiology, Bioactive Molecules, and Transcriptional Changes in Brassica rapa ssp. rapa Seedlings. Water Air Soil Pollut. 2019, 230, 48. [CrossRef]

29. Shekhawat, G.S.; Verma, K.; Jana, S.; Singh, K.; Teotia, P.; Prasad, A. In vitro biochemical evaluation of cadmium tolerance mechanism in callus and seedlings of Brassica juncea. Protoplasma 2009, 239, 31-38. [CrossRef]

30. Gill, S.S.; Tuteja, N. Reactive oxygen species and antioxidant machinery in abiotic stress tolerance in crop plants. Plant Physiol. Biochem. 2010, 48, 909-930. [CrossRef]

31. Yan, Q.-L.; Gozin, M.; Zhao, F.-Q.; Cohen, A.; Pang, S.-P. Highly energetic compositions based on functionalized carbon nanomaterials. Nanoscale 2016, 8, 4799-4851. [CrossRef]

32. Ahmad, R.; Pranaw, K.; Khare, S.K. Effect of Nanomaterials and Their Possible Implication on the Plants. In Plant Biotechnology: Progress in Genomic Era; Khurana, S.M.P., Gaur, R.K., Eds.; Springer Science and Business Media LLC: Berlin, Germany, 2019; pp. 213-229. [CrossRef]

33. Liang, T.B.; Yin, Q.S.; Zhang, Y.L.; Wang, B.L.; Guo, W.M.; Wang, J.W.; Xie, J. Effects of carbon nano-particles application on the growth, physiological characteristics and nutrient accumulation in tobacco plants. J. Food Agric. Environ. 2013, 11, 954-958.

34. Ghoto, K.; Simon, M.; Shen, Z.-J.; Gao, G.-F.; Li, P.-F.; Li, H.; Zheng, H.-L. Physiological and Root Exudation Response of Maize Seedlings to $\mathrm{TiO} 2$ and $\mathrm{SiO} 2$ Nanoparticles Exposure. BioNanoScience 2020, 10, 473-485. [CrossRef]

35. Wang, H.; Zhang, M.; Song, Y.; Li, H.; Huang, H.; Shao, M.; Liu, Y.; Kang, Z. Carbon dots promote the growth and photosynthesis of mung bean sprouts. Carbon 2018, 136, 94-102. [CrossRef]

36. Raliya, R.; Biswas, P.; Tarafdar, J. TiO2 nanoparticle biosynthesis and its physiological effect on mung bean (Vigna radiata L.). Biotechnol. Rep. 2015, 5, 22-26. [CrossRef] [PubMed]

37. Raliya, R.; Tarafdar, J.C. ZnO Nanoparticle Biosynthesis and Its Effect on Phosphorous-Mobilizing Enzyme Secretion and Gum Contents in Clusterbean (Cyamopsis tetragonoloba L.). Agric. Res. 2013, 2, 48-57. [CrossRef]

38. Rahal, A.; Kumar, A.; Singh, V.; Yadav, B.; Tiwari, R.; Chakraborty, S.; Dhama, K. Oxidative Stress, Prooxidants, and Antioxidants: The Interplay. BioMed Res. Int. 2014, 2014, 1-19. [CrossRef]

39. Nair, P.M.G.; Chung, I.M. Changes in the Growth, Redox Status and Expression of Oxidative Stress Related Genes in Chickpea (Cicer arietinum L.) in Response to Copper Oxide Nanoparticle Exposure. J. Plant Growth Regul. 2015, 34, 350-361. [CrossRef]

40. Nair, P.M.G.; Chung, I.M. Study on the correlation between copper oxide nanoparticles induced growth suppression and enhanced lignification in Indian mustard (Brassica juncea L.). Ecotoxicol. Environ. Saf. 2015, 113, 302-313. [CrossRef]

41. Shaw, A.; Hossain, Z. Impact of nano-CuO stress on rice (Oryza sativa L.) seedlings. Chemosphere 2013, 93, 906-915. [CrossRef]

42. Mahawar, L.; Khator, K.; Shekhawat, G.S. Role of Proline in Mitigating NaCl induced Oxidative Stress in Eruca sativa Miller: An important Oil Yielding Crop of Indian Thar Desert. Vegetos Int. J. Plant Res. 2018, 31, 55. [CrossRef]

43. Lu, Y.; Lei, J.-Q.; Zeng, F.-J.; Zhang, B.; Liu, G.-J.; Liu, B.; Li, X.-Y. Effect of NaCl-induced changes in growth, photosynthetic characteristics, water status and enzymatic antioxidant system of Calligonum caput-medusae seedlings. Photosynthetica 2017, 55, 96-106. [CrossRef]

44. Shankar, V.; Kumar, D.; Agrawal, V. Assessment of Antioxidant Enzyme Activity and Mineral Nutrients in Response to NaCl Stress and its Amelioration Through Glutathione in Chickpea. Appl. Biochem. Biotechnol. 2015, 178, 267-284. [CrossRef]

45. Tripathi, B.N.; Singh, V.; Ezaki, B.; Sharma, V.; Gaur, J.P. Mechanism of Cu- and Cd-Induced Proline Hyperaccumulation in Triticum aestivum (Wheat). J. Plant Growth Regul. 2013, 32, 799-808. [CrossRef]

46. Mahawar, L.; Shekhawat, G.S. Salt Induce Oxidative Stress and Its Tolerance Mechanism in Plant: Morphological, Biochemical And Molecular Perspective. Biotech Today Int. J. Biol. Sci. 2016, 6, 81. [CrossRef]

47. Ali, B.; Hayat, S.; Hasan, S.A.; Ahmad, A. Effect of root applied 28-homobrassinolide on the performance of Lycopersicon esculentum. Sci. Hortic. 2006, 110, 267-273. [CrossRef]

48. Amooaghaie, R.; Tabatabaei, F.; Ahadi, A. Alterations in HO-1 expression, heme oxygenase activity and endogenous NO homeostasis modulate antioxidant responses of Brassica nigra against nano silver toxicity. J. Plant Physiol. 2018, 228, 75-84. [CrossRef]

49. Srivastava, M.; Ma, L.Q.; Singh, N.; Singh, S. Antioxidant responses of hyper-accumulator and sensitive fern species to arsenic. J. Exp. Bot. 2005, 56, 1335-1342. [CrossRef]

50. Cakmak, I. Possible roles of zinc in protecting plant cells from damage by reactive oxygen species. New Phytol. 2000, 146, 185-205. [CrossRef]

51. Sandalio, L.; Dalurzo, H.C.; Gómez, M.; Romero-Puertas, M.; Del Río, L. Cadmium-induced changes in the growth and oxidative metabolism of pea plants. J. Exp. Bot. 2001, 52, 2115-2126. [CrossRef]

52. Husen, A.; Siddiqi, K.S. Carbon and fullerene nanomaterials in plant system. J. Nanobiotechnology 2014, 12, 16. [CrossRef]

53. Dimkpa, C.O.; McLean, J.E.; Latta, D.E.; Manangón, E.; Britt, D.; Johnson, W.P.; Boyanov, M.I.; Anderson, A.J. CuO and ZnO nanoparticles: Phytotoxicity, metal speciation, and induction of oxidative stress in sand-grown wheat. J. Nanoparticle Res. 2012, 14, 1125. [CrossRef]

54. Chandra, S.; Das, P.; Bag, S.; Laha, D.; Pramanik, P. Synthesis, functionalization and bioimaging applications of highly fluorescent carbon nanoparticles. Nanoscale 2011, 3, 1533-1540. [CrossRef] 
55. Wilkins, D.A. The Measurement of Tolerance to Edaphic Factors by Means of Root Growth. New Phytol. 1978, 80, 623-633. [CrossRef]

56. Arnon, D.I. Copper enzymes in isolated chloroplasts: Polyphenol oxidases in Beta vulgaris. Plant Physiol. 1949, $24,1-15$. [CrossRef]

57. Lowry, O.H.; Rosebrough, N.J.; Farr, A.L.; Randall, R.J. Protein measurement with the Folin phenol reagent. J. Biol. Chem. 1951, 193, 265-275. [CrossRef]

58. De Vos, C.R.; Schat, H.; Vooijs, R.; Ernst, W.H. Copper-induced Damage to the Permeability Barrier in Roots of Silene cucubalus. J. Plant Physiol. 1989, 135, 164-169. [CrossRef]

59. Alexieva, V.; Sergiev, I.; Mapelli, S.; Karanov, E. The effect of drought and ultraviolet radiation on growth and stress markers in pea and wheat. Plant Cell Environ. 2001, 24, 1337-1344. [CrossRef]

60. Bates, L.S.; Waldren, R.P.; Teare, I.D. Rapid determination of free proline for water-stress studies. Plant Soil 1973, 39, 205-207. [CrossRef]

61. Chen, G.-X.; Asada, K. Ascorbate Peroxidase in Tea Leaves: Occurrence of Two Isozymes and the Differences in Their Enzymatic and Molecular Properties. Plant Cell Physiol. 1989, 30, 987-998. [CrossRef]

62. Aebi, H. Catalase. In Methods of Enzymatic Analysis; Bergemeyer, H.U., Ed.; Academic Press: New York, NY, USA, 1974; pp. 673-684.

63. Putter, J. Peroxidase. In Methods of Enzymatic Analysis; Bergemeyer, H.U., Ed.; Academic Press: London, UK, 1974 ; pp. 685-690.

64. Beauchamp, C.; Fridovich, I. Superoxide dismutase: Improved assays and an assay applicable to acrylamide gels. Anal. Biochem. 1971, 44, 276-287. [CrossRef]

65. Balestrasse, K.B.; Noriega, G.O.; Batlle, A.; Tomaro, M.L. Involvement of heme oxygenase as antioxidant defense in soybean nodules. Free. Radic. Res. 2005, 39, 145-151. [CrossRef] 